Revista Española de Antropología Americana ISSN: 0556-6533

https://doi.org/10.5209/reaa.66528

\title{
Frente al antepasado: imágenes y discursos de poder en el entorno construido de Kohunlich
}

\author{
Daniel Salazar Lama ${ }^{1}$
}

Recibido: 5 de marzo de 2019 / Aceptado: 3 de mayo de 2019

Resumen. La incorporación de programas escultóricos en la arquitectura maya es una evidencia de la importancia de las imágenes en la producción de significados dentro del entorno construido. Los casos de estudio de esta investigación, los mascarones del Edificio A1 (o Templo de los Mascarones) y la crestería del Edificio B4 (o Palacio de las Estelas), ambos en Kohunlich, Quintana Roo, México, arrojan importante información sobre el comportamiento de las imágenes en el espacio público y su complementación con los componentes del entorno en la generación de mensajes relativos al ejercicio y al sustento ideológico del poder, a la sacralización de la figura real y a los conceptos religiosos básicos del gobierno.

Palabras clave: Kohunlich; Templo de los Mascarones; Palacio de las Estelas; iconografía; imágenes contextualizadas.

\section{[en] Facing the Ancestor: Images and Discourses of Power in the Kohunlich Built Environment}

\begin{abstract}
The incorporation of sculptural programs in Maya architecture is an evidence of the importance of images in meaning production within the built environment. The study cases of this research are the masks of Building A1 (Temple of the Masks) and the roofcomb of Building B4 (Palace of the Stelae) in Kohunlich, Quintana Roo, Mexico. Both provide important information about the behavior of the images in the public space and their complementation with other components of the environment in generating messages related to the ideological sustenance of power, the sacralized royal image and the basic religious concepts of government.
\end{abstract}

Keywords: Kohunlich; Temple of the Masks; Palace of the Stelae; iconography; contextualized images.

Sumario: 1. Introducción. 2. Análisis. 3. Discusión. Los edificios A1 y B4: imágenes y mensajes complementarios. 4. Conclusión. 5. Referencias.

Cómo citar: Salazar Lama, Daniel. 2019. «Frente al antepasado: imágenes y discursos de poder en el entorno construido de Kohunlich». Revista Española de Antropología Americana 49: 193-216.

\footnotetext{
1 Programa de Doctorado en Estudios Mesoamericanos, Universidad Nacional Autónoma de México; Centro de Estudios Mexicanos y Centroamericanos (CEMCA). danielsalazarlama@gmail.com.
} 
We consider monuments as cultural creations made for specific purposes, some of which can be inferred from the monuments themselves when viewed in context (Clark et al. 2010: 24)

\section{Introducción}

El presente trabajo se desprende de una investigación mayor enfocada en los personajes reales mayas representados en los programas escultóricos integrados en la arquitectura (Salazar 2019). Aquí me centraré en dos casos de estudio particulares y analizaré los mascarones de la fachada del Edificio A1 y la crestería del Edifico B4 de Kohunlich, en el sur de Quintana Roo, México, ambos construidos durante el período Clásico Temprano (200/250-600 d.C.) (véanse las Figuras 1 y 7, respectivamente).

De los dos programas escultóricos, los mascarones del Edificio A1 son los que han recibido mayor atención por parte de los investigadores. Entre las aportaciones más importantes destacan las hechas por Foncerrada de Molina (1983), Velázquez Morlet (1995), Baudez (2006) y Velásquez García (en Zetina 2007: 90-97). Todas concuerdan en identificar a los personajes representados como gobernantes exaltados mostrados en momentos liminares y asociados con los astros y el sol.

La crestería del B4 ha sido menos estudiada desde un enfoque iconográfico. Nalda y Balanzario (2005: 44; véase también Nalda 2004: 85) sugieren que en ella se representan seis personajes miembros de la realeza, y consideran a la imagen como expresión de un poder político compartido en Kohunlich.

Cabe destacar que estos mismos investigadores proponen que tanto los edificios A1 y B4 como sus programas escultóricos «funcionaron en algún momento del Clásico Temprano como un solo conjunto» (Nalda y Balanzario 2005: 44; cursivas del autor). Su interpretación se basa en evidencias arquitectónicas y espaciales (véase también Nalda et al. 1999; Nalda y Velázquez Morlet 2000: 30) e indagan brevemente en otros aspectos, como la naturaleza de los personajes representados y el contenido de las imágenes, por lo que los posibles vínculos semánticos entre ambos programas escultóricos es un tema aún por explorar.

Dentro del área maya existen sitios con diferentes elementos arquitectónicos y programas escultóricos que sí funcionaron como una unidad conceptual a pesar de la segmentación espacial y temática entre ellos (p.ej., templos del Grupo de las Cruces de Palenque; véase Stuart y Stuart 2008: Cap. 8), o que mantuvieron nexos simbólicos más allá de la distancia temporal que los separa (p.ej., Templo del Sol Nocturno y Plataforma de la Ascensión de El Zotz; véase Houston et al. 2015). Así, desde una perspectiva comparativa, la idea de que los programas escultóricos de los edificios A1 y B4 de Kohunlich pudieron comportarse como un conjunto es, en principio, enteramente viable.

Teniendo como punto de partida la idea de Nalda y sus colaboradores, el propósito de la presente investigación es intentar corroborar y comprender las posibles conexiones entre los mascarones del A1 y la crestería del B4; es decir, encontrar un significado integral y las formas con las que interactúan con su entorno. Para lograr dicho objetivo, el estudio de los programas escultóricos contemplará tres ejes analíticos fundamentales que ya fueron mencionados brevemente en la introducción de este dossier (Salazar y García Barrios en este volumen) y que he desarrollado y puesto en marcha en un trabajo reciente (Salazar 2019): 1) el formato plástico y la in- 

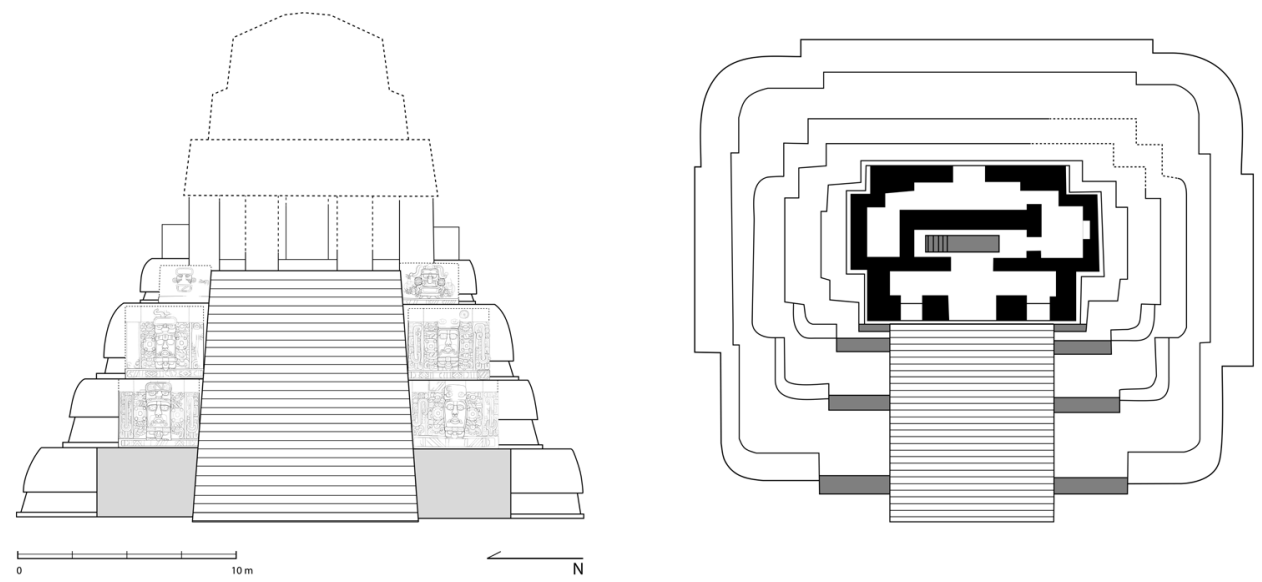

Figura 1. Edificio A1: alzado de fachada poniente y planta (dibujos de Daniel Salazar, basados en levantamiento y dibujo del Proyecto Arqueológico Sur de Quintana Roo, en Nalda et al. 1997).

formación visual de las imágenes, 2) el contexto arquitectónico (como una magnitud de significado que tiene un impacto en las imágenes) y el entorno físico en el que se integran (como un espacio comunicativo o de recepción), 3) las posibles circunstancias sociales involucradas en su producción.

El estudio se presentará como un ejercicio de contextualización en el que los programas escultóricos se analizarán de forma escalada y progresiva, siguiendo una propuesta metodológica que busca comprender las imágenes y su entorno circundante de manera integral (véase Salazar 2014: 31-37, 2019: Cap. 1). La intención es identificar los matices de significado que adquieren las imágenes en espacios concretos y sus niveles de participación en la generación de mensajes y significados dentro de un contexto más amplio.

\section{Análisis}

\subsection{Programa escultórico del Edificio A1 (ca. 200-400 d.C.)}

El Edificio A1 (o Templo de los Mascarones) originalmente tuvo ocho mascarones en la fachada poniente, aunque ahora solo seis de ellos son visibles (Figura 1). Los mascarones del $2^{\circ}$ y $3^{\text {er }}$ cuerpo (Figura 2) describen visualmente rostros antropomorfos que mezclan rasgos humanos y algunas características del dios solar K'inich, como las que se muestran en la Figura 3 a.

Todos los rostros se encuentran enmarcados por bandas celestes de las que cuelgan cabezas de serpientes estilizadas a ambos lados, y en la parte inferior por franjas horizontales con bandas diagonales e íconos de estrella. Juntos, estos motivos definen el ambiente celestial en el que se encuentran los personajes ${ }^{2}$.

\footnotetext{
2 La sección horizontal superior de las bandas celestes se ha perdido casi por completo en la mayoría de los mascarones, solo el mascaron 2S (y en menor medida el 3S) tiene restos de elementos icónicos en esa sección. Siguiendo las ideas de Martin (2016: 512), la orejera con marcas de brillo en la franja estelar del mascarón 3S podría indicar que se trata de un espacio radiante o luminoso.
} 


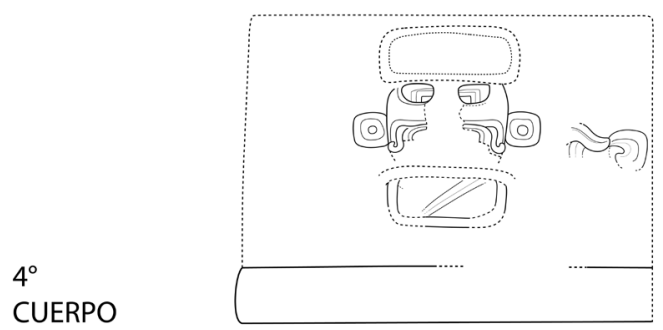

$4 \mathrm{~N}$

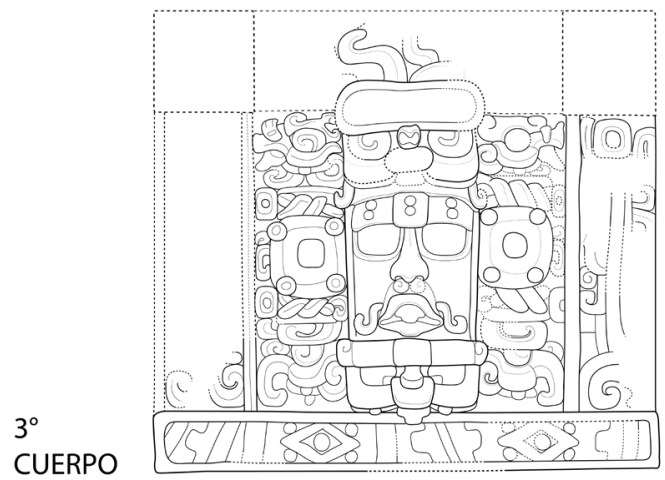

$3 N$

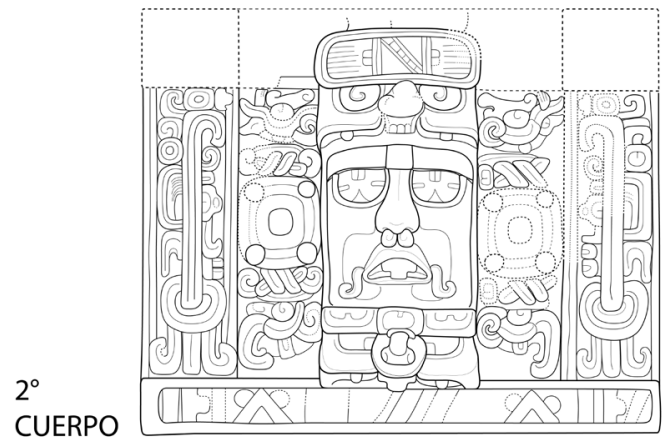

$2 \mathrm{~N}$

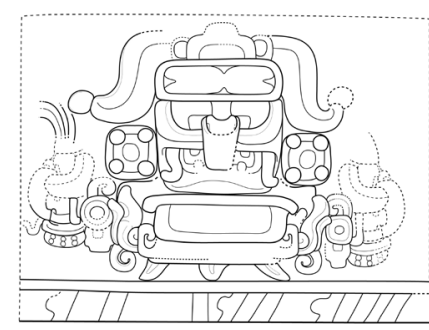

$4 S$

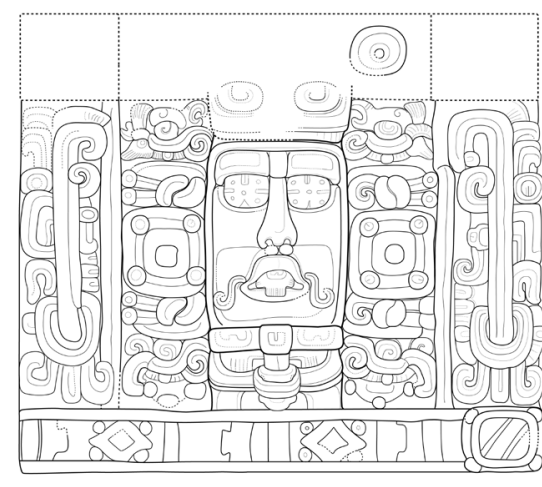

$3 S$

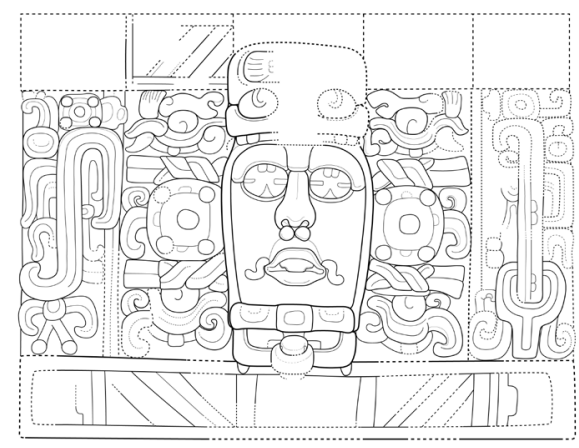

$2 S$

LADO SUR

Figura 2. Mascarones del Edificio A1 (dibujos de Daniel Salazar).

El atavío de rostro de los individuos representados es muy común en la plástica maya del Clásico Temprano y presenta una composición y constitución bastante estandarizadas. De manera general, se trata de un mapa simbólico o cosmograma que enfatiza la centralidad de los personajes principales (Salazar 2015: 22). Entre sus componentes se encuentran joyas de jade (p.ej., orejeras con cuentas) que conllevan nociones de estatus, riqueza y preciosidad, e insignias reales, como los motivos trenzados de estera (mascarones $2 \mathrm{~N}, 2 \mathrm{~S}, 3 \mathrm{~N}$ ) y los nudos con cuentas en el ensamble de las orejeras (mascarón 3S).

Otros componentes del atavío de rostro son las cabezas zoomorfas ubicadas debajo de los rostros centrales. En Kohunlich muestran rasgos estilizados de felinos, muy 

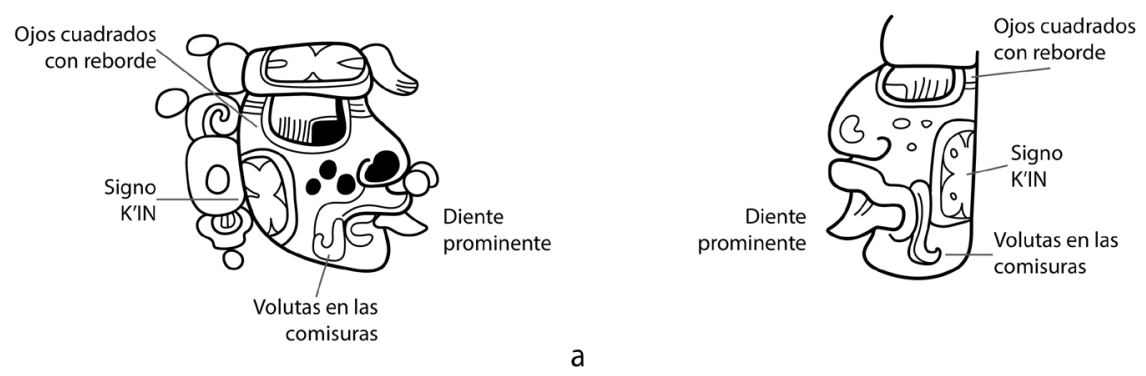

a

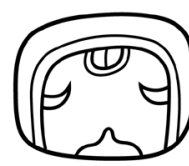

Signo T0521, WINIK

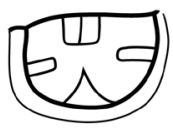

WINIK

en ojos de mascarón $2 \mathrm{~N}$
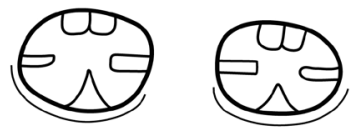

WINIK

en ojos de mascarón $2 S$

b

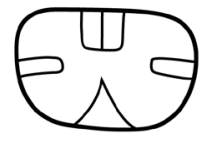

WINIK geometrico

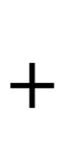

Signo $10544, K^{\top} \mathrm{IN}$

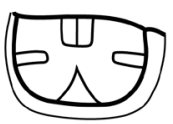

Figura 3. a) Rasgos de K'inich; b) signo WINIK y ojos de mascarones $2 \mathrm{~N}$ y 2S; c) composición de ojos del Mascarón 3S (dibujos de Daniel Salazar).

parecidos a otros ejemplares del Clásico Temprano (Figuras $4 a, b)^{3}$. Ya en otro trabajo (Salazar, en prensa) he propuesto que la relación entre estas cabezas zoomorfas y el rostro antropomorfo superior recrea una dualidad que confronta al sol nocturno (jaguar) con el diurno (rostro antropomorfo), pudiendo conformar ambos elementos una metáfora visual relativa a la transformación diaria del sol, tal como se observa en el mascarón de Yehnal en Copán (Figura 4e).

En los mascarones $2 \mathrm{~N}$ y $2 \mathrm{~S}$ los ojos de los rostros principales -cuya forma y tamaño claramente no son humanos- incluyen versiones geométricas del logograma WINIK, «hombre o persona» (Figura 3b). En la plástica maya en general los ojos de algunos dioses y criaturas incluyen elementos iconográficos que permiten un fácil reconocimiento (Houston y Taube 2000: 283-285). En ciertas deidades celestiales, por ejemplo, las pupilas son angulares y con marcas de brillo, mientras algunos dioses del inframundo o con características serpentinas poseen pupilas como volutas que recuerdan rizos de agua. Cabría pensar, por lo tanto, que los ojos contienen convencionalmente referencias gráficas relativas a la naturaleza de los personajes. Así, considero que en los mascarones $2 \mathrm{~N}$ y $2 \mathrm{~S}$ la incorporación del logograma WINIK es un ejemplo de asimilación pictórica entre iconografía y escritura, y que opera en un nivel denotativo, es decir, busca un mayor grado de especificidad en la imagen,

\footnotetext{
3 Los ojos de los jaguares en los mascarones de Kohunlich tienen pupilas angulares y marcas de brillo; rasgos que señalan su naturaleza solar.
} 


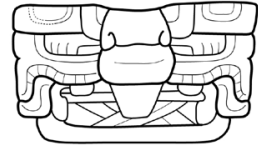

a

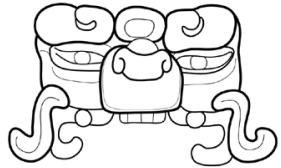

$\mathrm{b}$
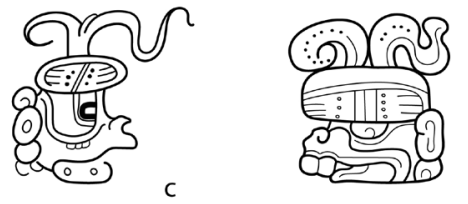

d
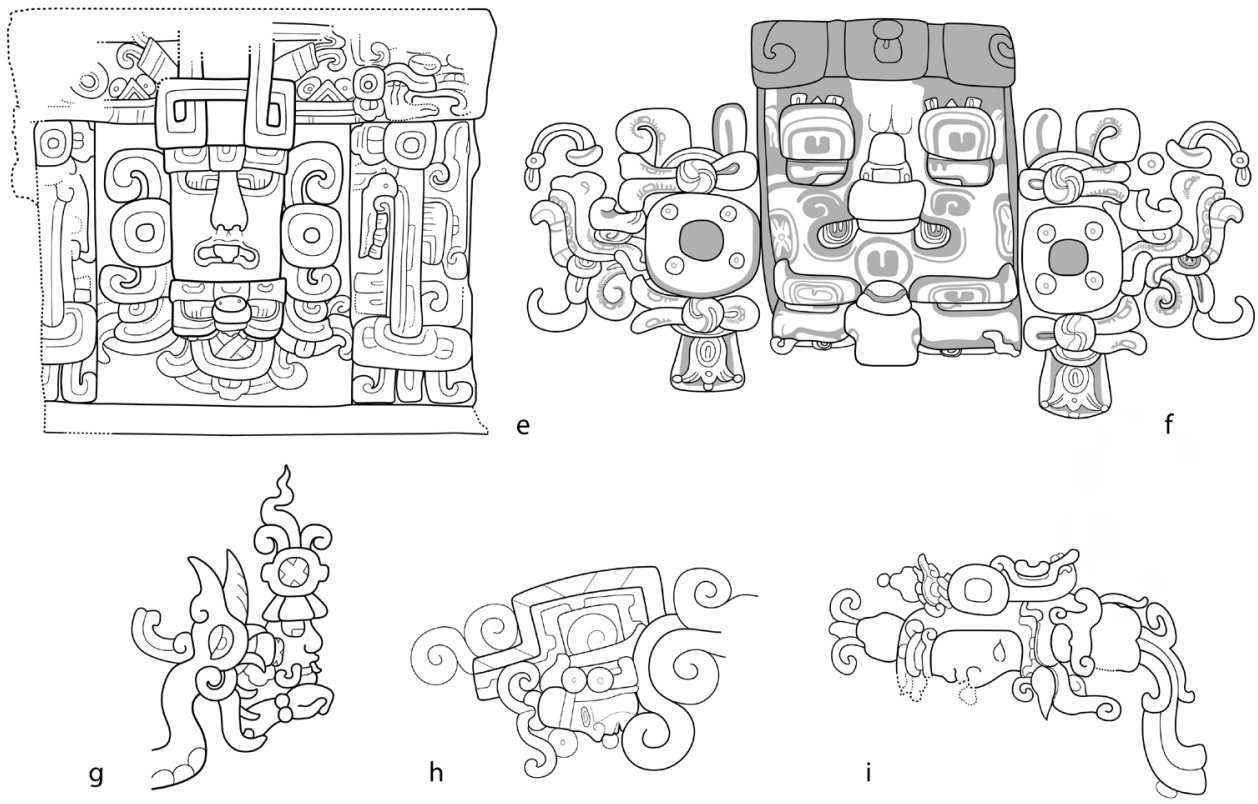

Figura 4. a) Jaguar en atavío de rostro en el friso del Edificio Pimiento, Xultún; b) jaguar en atavío de rostro en el friso de Placeres (MNA); c y d) signos K'AHK', «fuego», en variante de cabeza; e) mascarón del Edificio Yehnal, Copán; f) detalle del Mascarón de K'inich en Estructura 5C-2 ${ }^{\text {nd }}$ de Cerros; g) detalle de la Placa de Leiden; h) detalle de la

Estela 1 de El Baúl; i) antepasado en la sección superior de la Estela 29 de Tikal.

(Dibujos de Daniel Salazar).

favoreciendo la identificación de los componentes de la escena. Partiendo de su reconocimiento, propongo que el papel de este signo es definir la naturaleza humana de los individuos representados.

A diferencia de estos dos mascarones, el rostro del mascarón $3 \mathrm{~S}$ tiene ojos marcados con la variante geométrica de WINIK y el signo K'IN, «sol», infijo (Figura $3 \mathrm{c})$, reconocible a partir de los cinco puntos y por su forma cuadrilobular, misma que comparte con el signo WINIK geométrico, lo que propicia una efectiva convergencia gráfica entre ambos signos ${ }^{4}$. En la plástica maya, el signo K'IN también aparece en el rostro y la cabeza de $\mathrm{K}$ 'inich (Figura 3a), como uno de sus rasgos diagnósticos.

Considero que el signo compuesto por WINIK y K'IN en los ojos del mascarón $3 \mathrm{~S}$ funciona también como un recurso denotativo, indicando en este caso que el personaje es un ser dual, fusión de humano y dios solar.

En este mismo mascarón, el personaje tiene dos motivos ovalados incisos a la altura de la frente, mismos que por su forma y ubicación recuerdan a las marcas que a

\footnotetext{
${ }_{4}$ Para una opinión diferente de Velásquez García, consultar Zetina (2007: 93-97).
} 
veces lleva K'inich en esa misma sección del rostro (a manera de placas supraorbitales) aunque sin el ícono con forma de U (Figura 4f). Cuando se presenta con su forma completa, este tipo de motivos integrados en la frente corresponden con el llamado «ojo celestial» que generalmente pertenece a seres celestes o agentes humanos que personifican deidades solares (Kováč et al. 2016: 24); en el caso del mascarón 3S el elemento ovalado podría ser una abreviación icónica del motivo completo.

Por otra parte, el rostro del mascarón $3 \mathrm{~N}$-de aspecto distinto al anterior- tiene ojos casi cuadrados que recuerdan a los de K'inich, aunque en este caso están vacíos, y el personaje porta una especie de yelmo seccionado en tres placas, similar al que usa el dios solar en algunos mascarones del Preclásico (p.ej., mascarones de 5C-2 $2^{\text {nd }}$ de Cerros y de la Pirámide de Acanceh).

Las insignias humanas y solares que los personajes presentan en los ojos concuerdan con su fisonomía general, que mezcla rasgos humanos y de K'inich. Fusiones gráficas como estas son denominadas «interpenetraciones fundentes» por Carrere y Saborit (2000: 258-260), quienes las definen como la combinación en una misma imagen de elementos icónicos pertenecientes a distintas entidades, lo que genera una concurrencia absoluta de rasgos en el conjunto formado. De acuerdo con dichos autores (2000: 338 ) este recurso opera también como un mecanismo metafórico que otorga a las entidades fusionadas valores de connotación a partir de la relación de analogía perceptible entre ambas.

Un importante elemento del atavío de rostro de los cuatro mascarones son las cabezas zoomorfas a manera de tocados, de las cuales se elevan volutas (conservadas parcialmente en los mascarones $3 \mathrm{~S}$ y $2 \mathrm{~S}$ ). Por su forma general y sus componentes, estos motivos son similares al signo K'AHK', «fuego», de la escritura maya (Figuras $4 \mathrm{c}, \mathrm{d})$. En el contexto de los mascarones, no considero que dichos elementos mantengan su valor fonético $k^{\prime} a h k^{\prime}$, más bien se trata de representaciones gráficas de fuego.

Para poder explicar la presencia del fuego en estos tocados, primero haré un breve análisis de su significado en otros contextos relacionados.

García Barrios (2019, en este volumen) propone que la esencia del dios K'inich es el fuego, como materia solar y luminosa (ver también Tokovinine 2012: 289290), misma que se manifiesta a través del calor que emana su cuerpo. Esto se indica iconográficamente por medio de los signos K'IN, «sol» o «calor» ${ }^{6}$, que marcan sus extremidades, torso, mejillas y la frente o la cabeza. Particularmente interesante para este análisis es el signo K'IN que recurrentemente lleva sobre la cabeza (Figura 3a), ya que podría designar que es en esta parte del cuerpo donde reside el calor o la esencia misma del dios. Lo mismo parece mostrarse en otras imágenes e incensarios efigie del Clásico (Taube 2004: 275-277), que asocian la cabeza de K'inich con una fuente permanente de calor (véanse, por ejemplo, las cabezas de K'inich en los tocados de Yax K'uk' Mo' y de su sucesor en el Marcador Motmot de Copán); así como el dios solar que emerge de una serpiente bicéfala en la «Placa de Leiden» con el signo K'IN y llamas sobre la cabeza (Figura $4 \mathrm{~g}$ ).

\footnotetext{
5 Una fusión comparable entre un gobernante fallecido y K'inich se ve en el retrato de Yax Nuun Ahiin en la parte superior de la Estela 31 de Tikal (ver Figura 10b).

6 El signo K'IN, de lectura k'ihn o k'iin, se traduce como «calor», aunque k'iin también es «sol».
} 
El apelativo K'ahk' Ujol K'inich, «fuego es la cabeza de K'inich» (Colas 2003: 273), parece corroborar estas interpretaciones, aludiendo al fuego $-\mathrm{y}$ por extensión al calor- que se aloja en la cabeza de la deidad.

Estos planteamientos concuerdan con las investigaciones de Velásquez García (2015: 186-187), quien sugiere que para los mayas del período Clásico la frente y la coronilla eran los lugares del cuerpo donde residía la fuerza anímica o el espíritu del dios solar, su calor o k'ihn, asociado al nivel celeste y equivalente al toonalli en la cosmovisión nahua. De acuerdo con este mismo autor el calor era una cualidad que se incrementaba con la edad y que los gobernantes se adjudicaban y expresaban, tanto en los textos como en la imaginería del Clásico.

Quizá por esta razón algunos antepasados reales que ocupan el cielo en su apoteosis solar tienen llamas y volutas de humo en la cima de la cabeza (p.ej., antepasados en las Estelas 1 de El Baúl y 29 de Tikal -Figuras 4h-i, respectivamente-) $)^{7}$, indicando con ello la esencia o el espíritu de K'inich acumulado a lo largo de los años y que se manifiesta físicamente en momentos y espacios liminares, cuando se fusionan de manera parcial con el dios.

A partir de estas interpretaciones, una posible explicación para la presencia de fuego en los tocados de los mascarones de Kohunlich, es que, al igual que las llamas en la cabeza de los antepasados celestiales de las estelas de Tikal y El Baúl, representa la esencia calorífica (ígnea) que los personajes humanos comparten con K'inich y que se hace tangible o visible en momentos de transformación y fusión con el dios. Un significado del fuego complementario a éste se puede encontrar en su estrecha relación con los momentos de transfiguración y emergencia solar, cuando funge como el elemento que propicia o favorece tales episodios (Taube 2004: 275-277). Estas interpretaciones se refuerzan con la dualidad que se produce entre los rostros principales y las cabezas de felinos ubicados debajo de la barbilla, en el sentido que dicha relación recrea la transformación del sol nocturno en un sol diurno encarnado por personajes humanos vinculados metafóricamente con K'inich.

Finalmente, el mascarón 4S (ver en Figura 2) muestra la cabeza de la Deidad Ave Principal en vista frontal y dos cabezas más de perfil, una a cada lado, con rasgos solares (comparar con Figuras 5a, b). Todo el compuesto tríadico se encuentra sobre una banda con marcas de brillo que define un espacio celeste y luminoso.

La cabeza central es la más completa y tiene los siguientes rasgos distintivos: un signo K'IN en la frente, un signo ajaw foliado sobre la cabeza y, debajo, un plato y un pectoral terminado en tres puntas, muy parecido al que porta la deidad aviar cuando se presenta de cuerpo completo (Figuras $5 \mathrm{a}, \mathrm{b})^{9}$.

El signo K'IN sobre la frente es comparable con la marca diagnóstica de K'inich (Figura 3a) y es un claro indicador de la naturaleza solar del ave y de su parentesco con $\mathrm{K}^{\prime}$ inich ${ }^{10}$, mientras que el ajaw foliado permite identificarla como Ux Yop Huun,

7 Existen muchas imágenes de antepasados celestiales de cuyas cabezas emana fuego y humo. Algunas pueden consultarse en Finamore y Houston 2010: cat. n70, 73 y 74.

8 Consultar también Nielsen y Helmke (2018) para un análisis más amplio acerca de las funciones transformadoras del fuego en la cosmovisión teotihuacana y mesoamericana en general.

9 Las cabezas de serpientes que se encuentran a ambos lados del pectoral recuerdan al ofidio bicéfalo de cuerpo enroscado que el ave sostiene con el pico en otros ejemplos del Clásico. En algunas ocasiones las serpientes aparecen con un aspecto igualmente estilizado, aunque con rasgos ligeramente distintos (véase Figura 5a; Hellmuth 1987: Figuras 544 y 549).

${ }^{10}$ Este signo también podría designar al ave de 4S como una deidad específica. En el mural de la Tumba 12 de Río Azul se encuentra una variante de esta ave llamada K'in Tz'ikiin Ajaw, «Señor ave sol» (Helmke y Nielsen 2015: 

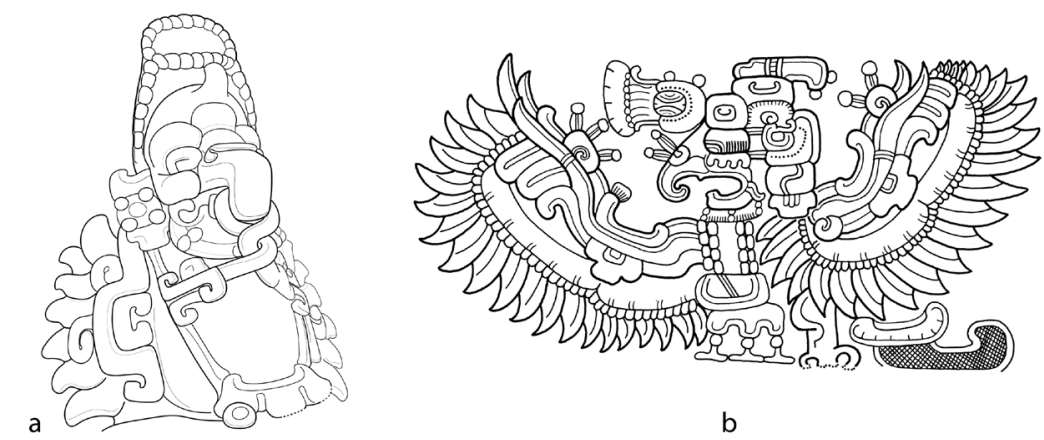

b
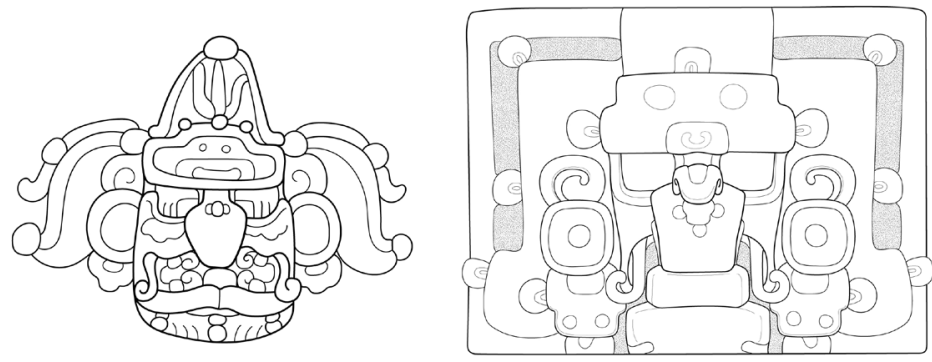

d
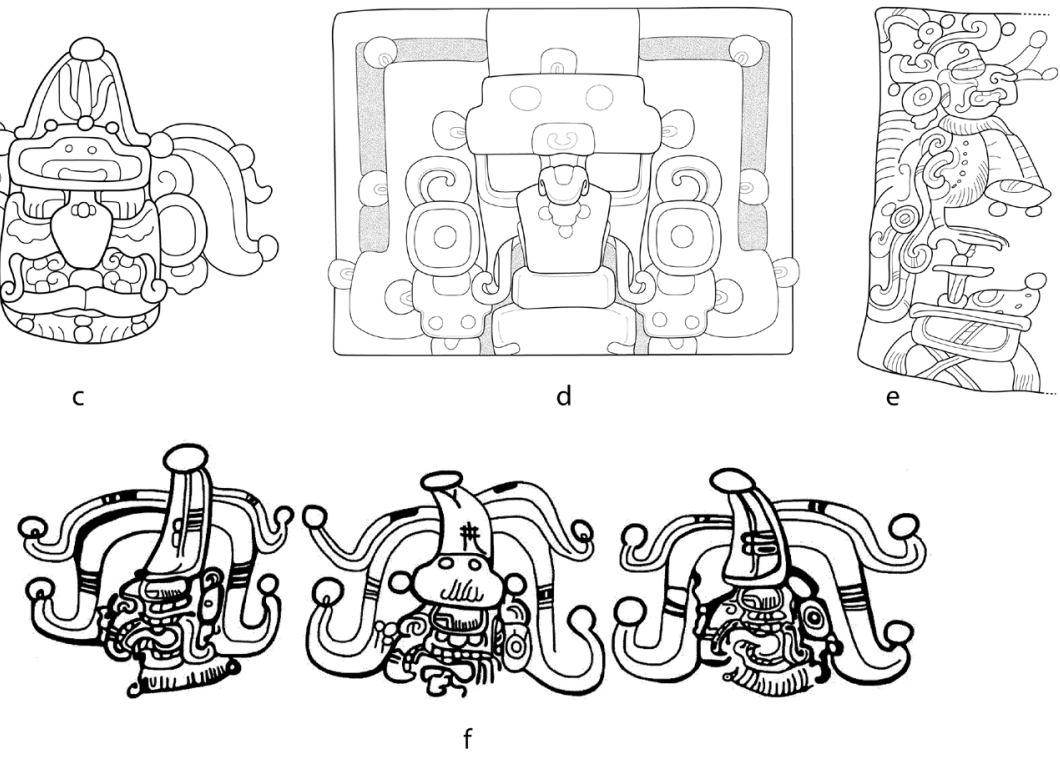

Figura 5. a) Deidad Ave Principal de cuerpo completo. Detalle de una vasija modelada proveniente de la Tumba 2 de la Estructura IV-B de Calakmul (ca. 500-560 d.C.); b) Deidad Ave Principal de cuerpo completo en una vasija del Clásico Temprano proveniente de saqueo; c) joya real Ux Yop Huun. Cabeza de jade encontrada en la Tumba B 4/7 de Altun Há; d) Mascarón $n^{\circ} 1$ (perteneciente a un conjunto de tres mascarones similares alineados) de la Estructura M7-1 de El Zotz; e) detalle de la vasija K3801; f) mural de la Tumba 19 de Río Azul (desplegado). (Dibujos: a, c, d y e, Daniel Salazar; b, Susanna Reisinger; f, dibujo de P. Steinbach modificado por el autor).

una insignia real que era atada a la cabeza o la frente de los gobernantes en ceremonias de entronización (Stuart 2012). Véase comparativamente la Figura 5c.

Más allá de estas observaciones iconográficas, la disposición tríadica de las cabezas de ave en el mascarón $4 \mathrm{~S}$ remite a un simbolismo más complejo. En varios contextos arquitectónicos, por ejemplo en los mascarones de la fachada del Edificio M7-1 de El Zotz y en el mural de la Tumba 19 de Río Azul (Figuras 5d y f, respecti-

27), mientras que en una orejera de procedencia desconocida (Taube et al. 2010: Figura 36A) la misma ave se identifica por el signo solar que lleva sobre la cabeza. 
vamente), los conjuntos de tres Ux Yop Huun parecen corresponder con un principio de orden cosmológico básico que se asocia frecuentemente con dioses patronos de linajes y con antepasados reales (Stuart 2017: 257), y que podría enfatizar el centro como punto axial del cosmograma que además conecta los distintos planos verticales del cosmos (Taube 1998). En Kohunlich, esta recreación cosmológica tiene un marcado carácter celeste debido a la banda horizontal inferior que define el tipo de espacio en el que se ubica.

El último detalle de este mascarón es el plato debajo de la cabeza central. Su forma es parecida a la del «Tazón k'in» aunque carece del característico signo cuadrilobular en el centro (compárese con Stuart 2010: figs. 129a, b). Sospecho que originalmente tuvo marcas de brillo pintadas, similares a las del plato del mascarón $4 \mathrm{~N}$ (ver en Figura 2). En la vasija K3801 (Figura 5e) la Deidad Ave Principal se coloca sobre un plato similar al de Kohunlich, claramente asociado con la emergencia y el renacimiento solar por los elementos iconográficos que lo vinculan con el Tazón k'in, que es interpretado como el portal para el ascenso diario del sol (Stuart 2010: 166-168).

Debido a la presencia de este plato y a su posible vínculo con el simbolismo del Tazón k'in, sugiero que su función en la imagen del mascarón $4 \mathrm{~S}$ es designar el punto del levantamiento del sol dentro de un esquema tríadico y celeste.

Al intentar ver la escena completa de la fachada del A1, detecto que cada uno de los cuerpos del basamento se enfoca en distintas representaciones: el segundo cuerpo muestra dos personajes que ocupan un espacio celeste y que presentan los rasgos fisonómicos y la esencia ígnea de K'inich, aunque con marcas que indican claramente su naturaleza humana; el tercer cuerpo contiene representaciones de personajes -también en un entorno celestial- que fusionan más explícitamente su naturaleza humana con la del dios solar, adquiriendo sus insignias características y sus rasgos de manera más acentuada; y en el cuarto cuerpo -con solo un mascarón conservado del lado sur- se recrea una estructura cosmológica celeste asociada con el punto de ascenso solar.

A la luz del análisis anterior planteo que el tema desarrollado en el programa escultórico del Edificio A1 de Kohunlich es el proceso de fusión de agentes humanos (miembros de la realeza) con el dios K'inich en un momento liminar; proceso que se desarrolla en un ámbito celestial y que es mostrado como una transformación gradual a través de la cual los personajes adquieren los rasgos y las insignias del dios solar a medida que suben por los cuerpos del basamento. Al mismo tiempo, las cabezas de ave con arreglo tríadico en la sección superior enlazan a los individuos con una estructura cosmológica, aludiendo tal vez a un punto específico del plano celeste donde se llevará a cabo la transformación final de los personajes.

\subsection{El programa escultórico en contexto}

El Edificio A1 se encuentra en la cima de una colina baja con terrazas y remanentes de posibles muros de retención, dominando el entorno construido del grupo central de Kohunlich. A sus pies se halla un amplio espacio abierto de carácter público, posiblemente una antigua plaza desde la cual el edificio se ve hacia el oriente (Nalda y Velázquez Morlet 2000: 30). A su vez, el A1 se encuentra en la misma línea visual del Edificio B4 y su crestería, conformando un eje este-oeste sobre el que también se construyó la Plaza de las Estelas (Figura 6). 


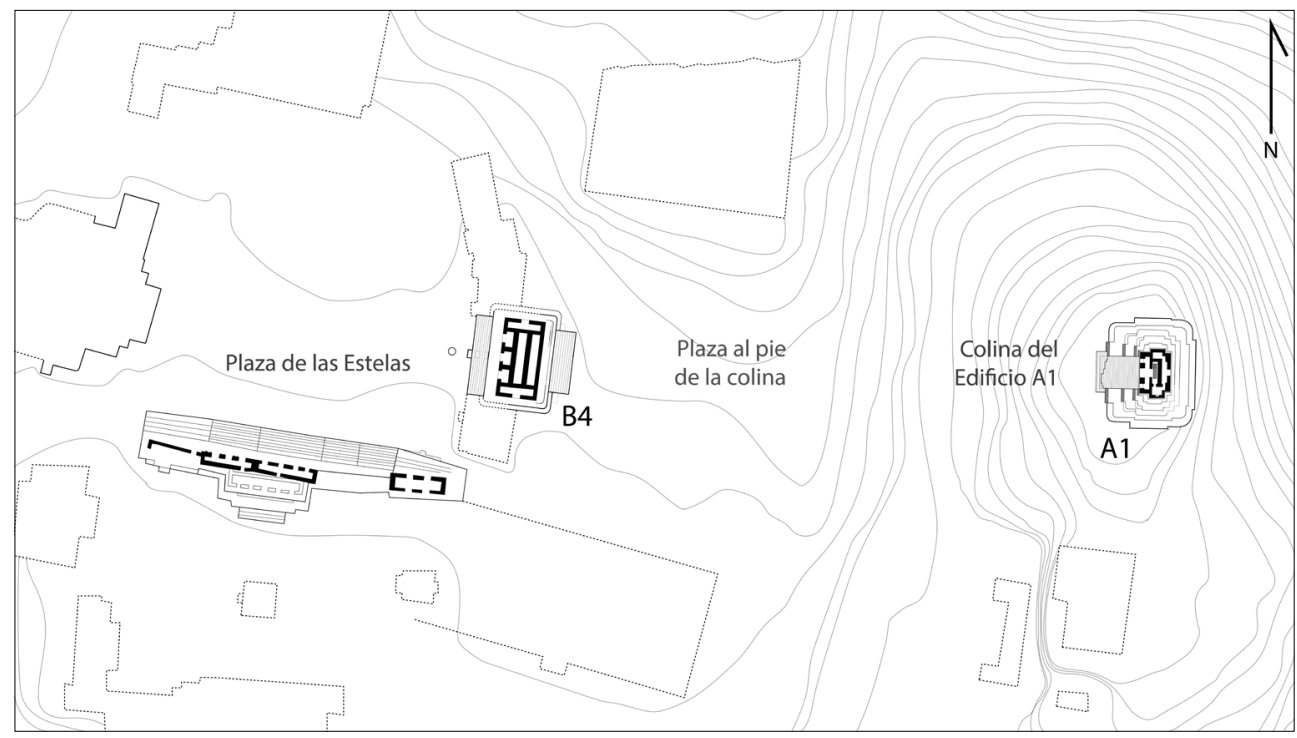

Figura 6. Plano del área central de Kohunlich (dibujo de Daniel Salazar, basado en levantamiento previo del Proyecto Arqueológico Sur de Quintana Roo, en Nalda 2004).

El A1 consta de dos etapas constructivas, la primera corresponde al lapso 200400 d.C. (Figura 1) y es a la que pertenecen los mascarones ${ }^{11}$. A esta fase también corresponde una cámara funeraria construida debajo de una de las crujías del templo superior. Se encontró saqueada, aunque con fragmentos de jade y de concha tallada, lítica, una espina de mantarraya, restos de cerámica y un plato polícromo (Nalda et al. 1997: 3). Las características morfológicas de esta tumba fueron estudiadas por Balanzario y Nalda (2009); a partir de sus observaciones y tomando en cuenta la aparente riqueza de la tumba del Edificio A1 y su ubicación dentro del espacio público, considero que se trata de un recinto funerario real.

La particular ubicación del Edificio A1, la cripta en su interior y la actividad constructiva son características que concuerdan con los monumentos funerarios reales que fungen como lugares de veneración de los gobernantes muertos. Siguiendo los planteamientos de McAnany (1998), y de Rich y Matute (2014: 67-70), considero que el simbolismo de estos recintos está supeditado a la incorporación de los soberanos, cuya presencia se manifiesta en sus restos físicos y en imágenes que los representan; simbolismo en el que también influyen las funciones intrínsecas del lugar. Al respecto, durante todo el período Clásico las tumbas reales fueron sitios aptos para la transformación, configurándose como los puntos de partida para el ascenso y el tránsito cosmológico de los gobernantes fallecidos (Ashmore y Geller 2005: 84; Hull 2006) ${ }^{12}$.

\footnotetext{
11 Según Nalda y sus colaboradores (Nalda et al. 1997: 3), el aspecto original del Templo de los Mascarones permaneció inalterado hasta la segunda fase constructiva realizada a inicios del siglo VII, y que incluyó un reacondicionamiento del acceso al templo y la construcción de un andador que cubrió por completo el primer cuerpo de la estructura (Alan Maciel, comunicación personal, julio de 2015). En esta segunda edificación también se construyeron nuevos mascarones que taparon los originales dispuestos en el primer cuerpo. Para una interpretación sobre estos mascarones véase Salazar (en prensa): «El templo de los mascarones de Kohunlich; una interpretación simbólica».

${ }_{12}$ Para el período Clásico, estas consistencias se pueden detectar en varios recintos funerarios, por ejemplo, en las
} 
De esta forma, planteo que el Edificio A1 funciona como una magnitud de significado que toma parte en los contenidos expresados por las imágenes. Esto me lleva a sugerir que los mascarones integrados en dicha estructura no son objetos enteramente autónomos, y que prevén la participación del entorno en su significación. Así, cabe preguntarse si dentro de este particular contexto el programa escultórico adquiere connotaciones adicionales.

Recordemos que los mascarones muestran la fusión gradual entre personajes reales y el dios K'inich en un espacio celestial. Ubicando dicha escena en el este -que es hacia donde se observa el A1- es viable sugerir que los mascarones aluden al gobernante sepultado en el adoratorio que corona la estructura, mostrándolo en un proceso de concurrencia con el dios solar en el instante de elevarse en el cielo por el oriente.

Para los mayas del Clásico, las transformaciones que experimentaron los gobernantes muertos y su afinidad con el sol saliente fueron entendidas como una especie de renacimiento que implicó emerger del inframundo acuático al que se ingresa al morir ${ }^{13}$. Una clara evidencia de estos conceptos se encuentra en el mural de la Tumba 1 de Río Azul, que recrea un espacio acuático en cuyo centro fue sepultado un posible rey, mientras en el texto pintado en el muro este se utilizó el verbo sihyaj, «nacer», para aludir a su posterior surgimiento (Coggins 1988: 74; Acuña 2015: 178). Esta interpretación concuerda con lo que han propuesto Coggins (1988) y Baudez (2006), para quienes una forma de conceptualizar la vida de los gobernantes mayas fue estableciendo un paralelismo con el ciclo solar, equiparando su surgimiento del mundo de los muertos con el levantamiento del sol por el oriente y su muerte como el sol en el ocaso.

En la escena del Edificio A1, la simultaneidad espacial del personaje se explica si consideramos que las repeticiones de un mismo referente con variaciones icónicas muestran distintos estados o momentos de su presencia. Así, es posible que la escena muestre dos aspectos del dios solar encarnados por el mismo gobernante, cada aspecto representado en uno de los lados del edificio (norte y sur). De esta forma, al ser representado como el dios solar, el agente humano manifiesta sus mismas características conductuales y sus facultades sobrehumanas.

En síntesis, la escena en su totalidad recrea la secuencia de transformación y renacimiento solar del gobernante dentro de una estructura cosmológica; proceso que inicia y se lleva a cabo en el lugar mismo de su enterramiento.

De esta forma el Edificio A1 de Kohunlich adquiere un sentido narrativo, es decir, logra conectar los significados de las tematizaciones visuales con las circunstancias extra pictóricas (o extra escultóricas) dictadas por el contexto, con el propósito de recrear y materializar un acontecimiento dentro del entorno construido (para un estudio pormenorizado del sentido narrativo de los edificios en conjunto con las imágenes, consultar Salazar 2019).

\subsection{Programa escultórico del Edifico B4 (ca. 450-600 d.C.)}

El programa escultórico del Edifico B4 (o Palacio de las Estelas) consta de una crestería seccionada en tres bloques, cada bloque tiene dos caras opuestas con relieves

tumbas del Clásico Temprano en Río Azul (Acuña 2015) y en la tumba de K’inich Janaab' Pakal en Palenque (Stuart y Stuart 2008: Cap. 7).

${ }^{13}$ El verbo och ha', «entrar en el agua», fue una expresión metafórica para la muerte. 


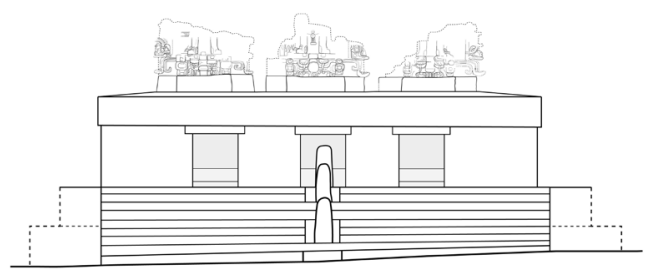

a

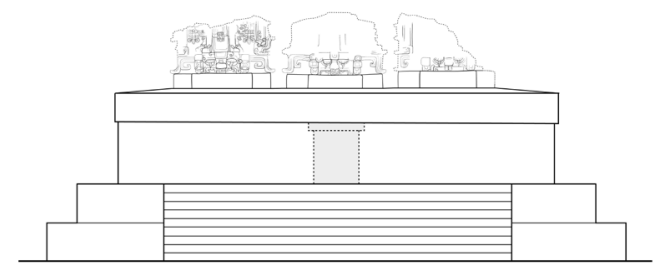

b

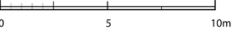

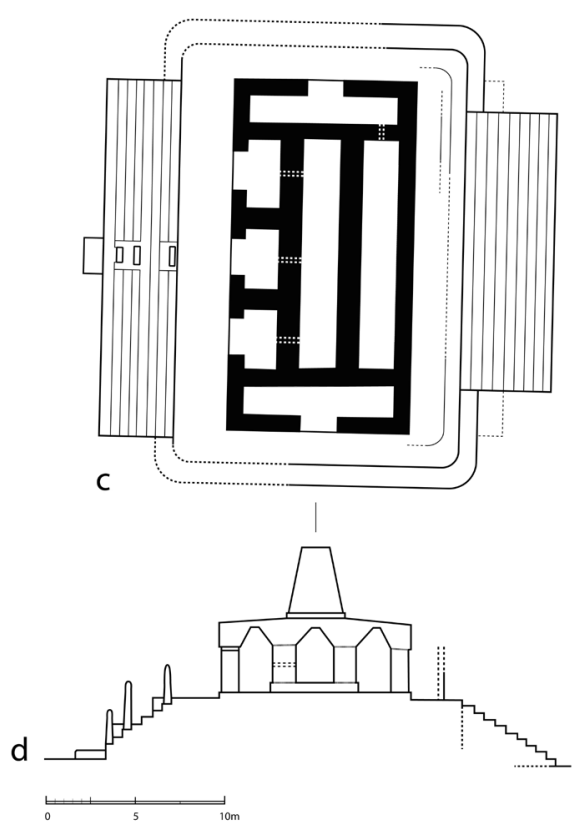

Figura 7. a) Edificio B4, fachada poniente; b) Edificio B4, fachada oriente; c) planta del Edificio B4; d) corte transversal del Edificio B4 (dibujos de Daniel Salazar, basados en levantamientos previos del Proyecto Kohunlich, en Nalda et al. 1999).

de estuco, conformando en conjunto una crestería de dos frentes y seis segmentos (Figuras $7 \mathrm{a}, \mathrm{b}$ ). La escena describe visualmente seis personajes con elementos de parafernalia real y situados sobre cabezas zoomorfas (Figura 8).

Estas cabezas corresponden con imágenes de montañas -witz- de las que surgen foliaciones de maíz, aunque sin rasgos distintivos que las designen como localidades específicas. Sobre ellas se sitúan tronos configurados a partir del cuerpo bicéfalo de criaturas zoomorfas con una estera (para más detalle, véase Figura 9a).

Sobre estos tronos se encuentran personajes con rasgos corporales humanos; cada uno conforma el eje y tema central de su segmento. Todos los personajes están vestidos a la usanza de las figuras reales o de alto rango, con elementos trenzados de los que cuelgan tres placas ovales (segmento 1E) o joyas con cuentas (segmento 2O), con extensiones de tela que caen de la parte frontal del braguero (segmento 1E) y con sandalias (segmentos 1E, 1O, 2O). Además, todos presentan una postura corporal sedente que alude al rango y a la jerarquía real y que expresa la noción misma de entronizar $\mathrm{u}$ ocupar el trono. Por estas razones, es fácil identificar a los seis individuos representados como figuras reales.

Gracias a la presencia de tronos -como asientos reales- sobre montañas las imágenes de la crestería aluden a ciertas localidades y a la autoridad ejercida sobre ellas. Una interpretación parecida ya había sido postulada por Baudez (1995: 153), quien definió las representaciones de gobernantes parados o sentados sobre montañas como expresiones gráficas del dominio sobre un territorio y con claras alusiones a una dimensión política. De igual manera, García Capistrán (2019) plantea que los mascarones witz con tales características podrían representar el concepto de kab' $c h$ 'e' $n$, que en los textos del Clásico fue utilizado para definir un territorio goberna- 


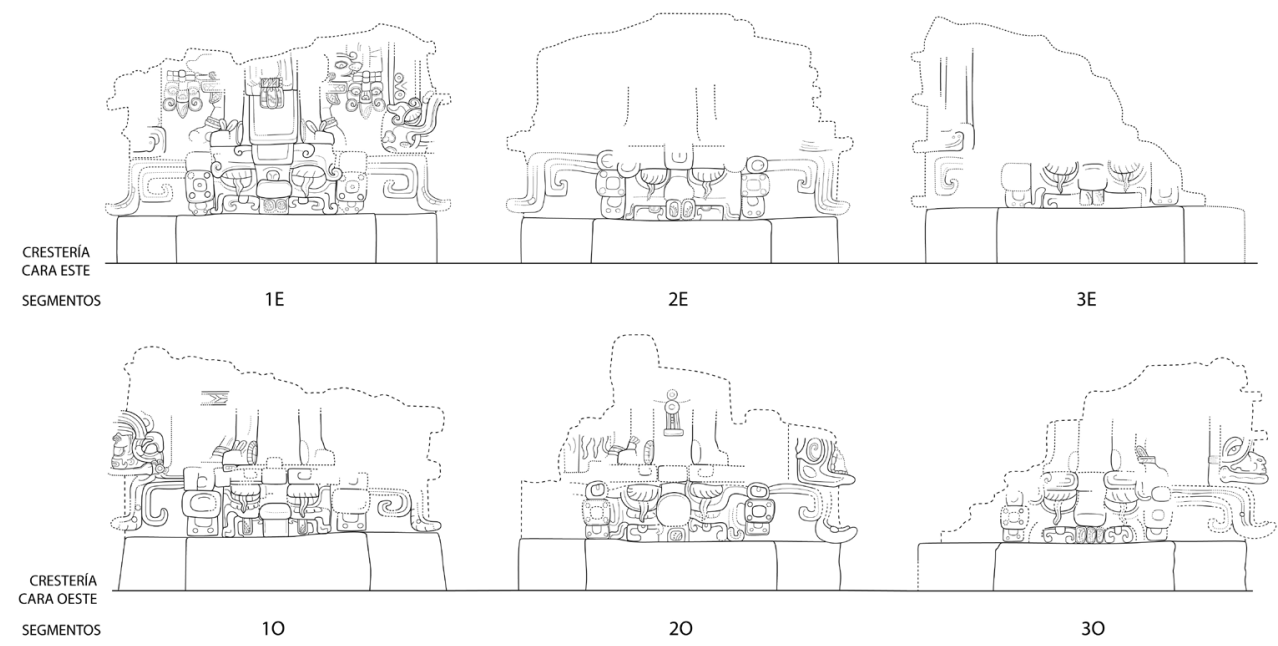

Figura 8. Crestería del Edifico B4. a) cara poniente; b) cara oriente (dibujos de Daniel Salazar).

do. En la crestería del B4, las cabezas witz también expresan ideas cosmológicas y de fertilidad asociadas a la jurisdicción real; la abundancia vegetal estaría indicada por los brotes de maíz.

Escenas parecidas predominan en este tipo de formatos escultóricos. Gendrop (1984: 29-30) menciona que la imagen de gobernantes de pie o sentados sobre mascarones es recurrente en los programas dinásticos en las cresterías del Clásico.

Ahora bien, en los seis segmentos aparecen, a ambos lados de los personajes y a la altura de los pies, cabezas de criaturas zoomorfas orientadas hacia el exterior; de sus fauces abiertas emergen pequeños rostros. Estas cabezas zoomorfas concuerdan con los extremos de extensiones verticales de ciertas barras ceremoniales, como la que se ve en la Estela 20 de Caracol (Figura 9c) y en otros ejemplos del Clásico Temprano ${ }^{14}$.

Cada una de las barras ceremoniales de la crestería del B4 es marcadamente diferente: las cabezas de las criaturas en sus extremos son variadas, desde serpientes (segmento $1 \mathrm{E}$ ) hasta cabezas esqueléticas de ciempiés (segmento 1O, comparar con los monumentos de Copán CPN 1, CPN 18 y CPN 47, cara oeste [en Baudez 1994, Fig. 4, 26 y 61, respectivamente]); a su vez, de estas cabezas emergen seres distintos: un posible personaje humano en el segmento $3 \mathrm{O}$ y un dios en las fauces esqueléticas del segmento 1O. Un detalle único que se ha conservado en el segmento $1 \mathrm{E}$ es un signo de estrella, similar al de la Estela 20 de Caracol y a otras serpientes cósmicas sostenidas por gobernantes (p.ej., pectoral de concha de la Tumba del Templo del Búho en Dzibanché). En el segmento 1E el signo de estrella define el cuerpo de la serpiente como una banda celeste, lo que concuerda con las llamadas «serpientes estrelladas» por Stuart (2004: 139).

Pese a las diferencias en sus componentes internos, las barras ceremoniales y las criaturas serpentinas que se integran a ellas fueron símbolos esenciales del poder

\footnotetext{
${ }^{14}$ En la crestería del B4 los brazos y las manos de los personajes debieron tener una postura similar a la del personaje principal del friso del Edificio Pimiento de Xultún (Figura 9b).
} 


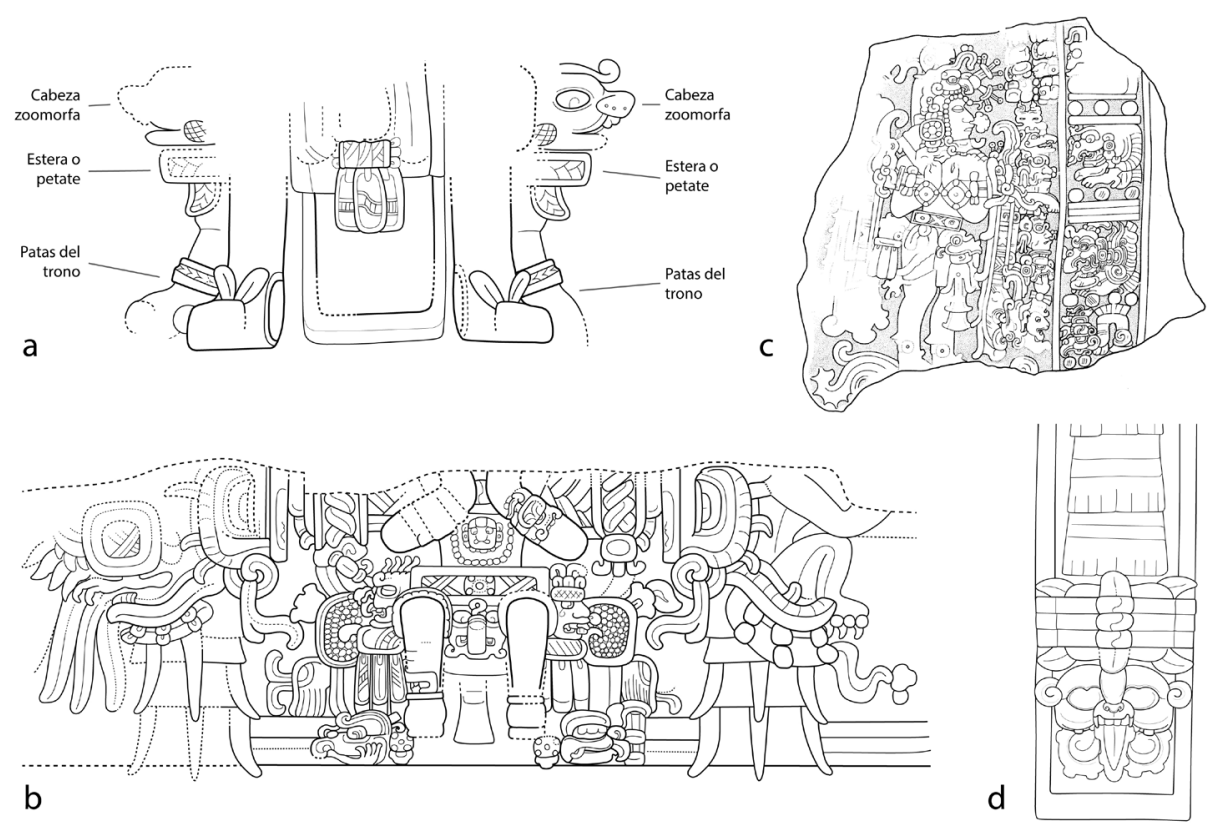

Figura 9. a) Detalle de la crestería del Edificio B4: Segmento 1E con trono señalado; b) personaje central del friso del Edificio Pimiento, Acrópolis Los Árboles, Xultún; c) Estela 20 de Caracol; d) relieve de estuco de la Estructura D5-1 de Toniná (dibujos: a, b, d, Daniel Salazar; c, Nikolai Grube).

real y de los deberes rituales de los soberanos. Fungían como conductos cosmológicos por los que emergían dioses y antepasados previamente conjurados; por ello, la habilidad para usarlas y controlarlas era un privilegio exclusivo de los nobles y los reyes. Según Stuart (2004: 138) este era uno de los principales complejos rituales de la realeza, con el que además se expresaba el trasfondo religioso del reinado.

En el segmento 1E, entre los extremos de los tronos y las barras ceremoniales, fueron colocadas dos cabezas de jaguares con elementos anudados en la parte superior, con lenguas de cuchillos y volutas en las fauces ${ }^{15}$. Cabezas parecidas en las alfardas del Edificio D5-1 de Toniná (Figura 9d) son interpretadas por Baudez (2013: 199-200) como alusiones al autosacrificio gracias a las volutas de sangre y a la lengua con forma de espina de mantarraya. Un simbolismo afín podría tener el par de jaguares del segmento 1E, siendo su cercanía con las barras ceremoniales una alusión al derramamiento de sangre necesario en los rituales de invocación.

Otra posible explicación para estos jaguares es que aluden a la guerra y al sacrificio de cautivos. Esta idea se sustenta al observar que los posibles pendones de tela que están por encima de ellos se asocian en otros monumentos a cabezas de cautivos sacrificados (p.ej., relieve de la «Cuatro eras» de Toniná y relieves de la fachada oeste del Templo del Sol Nocturno de El Zotz); asimismo, los nudos sobre las cabezas de los felinos y la lengua de cuchillo son símbolos marciales (Velásquez 2006: 125), y aparecen comúnmente en báculos de guerra o en lanzas ${ }^{16}$.

\footnotetext{
${ }^{15}$ Estas cabezas de felino parecen no haber estado en todos los segmentos de la crestería (p.ej., segmento 2O).

${ }^{16}$ La imposibilidad para dar una interpretación más concreta sobre estos felinos radica en que se desconocen los
} 
En síntesis, cada segmento de esta crestería repite imágenes muy similares configuradas a partir de los mismos motivos iconográficos, aunque con ciertas variantes. En ellos se presentan personajes entronizados rodeados de parafernalia real y efectuando rituales sagrados propios de la nobleza regente, con alusiones a territorios gobernados y con símbolos de guerra y de sacrificio. Partiendo de esta observación, es posible reconstruir el tema del programa escultórico del Edificio B4 como la expresión del oficio del poder a manos de seis figuras reales, quienes además se muestran asociados con localidades sobre las que se fundamenta y ejerce su autoridad.

Ante esta escena múltiple surge la duda sobre cuantos personajes están representados, si son seis distintos o solo unos cuantos repetidos bajo diferentes aspectos. Debido a la pérdida de muchos elementos iconográficos, sospecho que será el contexto espacial de la crestería el que ayudará a resolver este asunto.

\subsection{La escena de la crestería del B4 en contexto}

El Edificio B4 es un palacio con por lo menos cinco etapas constructivas que abarcan el Clásico Temprano y los inicios del Tardío. Durante la tercera fase constructiva (450-600 d.C.) tuvo tres pequeños cuartos y cuatro largas y angostas galerías (Figura 7c); asimismo, contó con dos fachadas principales, una orientada al Edificio A1 y viendo de frente a los mascarones y a la plaza al pie de la colina, y otra hacia la Plaza de las Estelas (Figuras 7a, b), ambas conectadas por un andador que facilitaba la movilidad de una fachada a otra ${ }^{17}$. A cada fachada corresponde una escalinata de acceso, una ancha plataforma al frente y una de las caras de la crestería (Figura 7d). Estas particularidades señalan la funcionalidad de ambas caras del edificio, a pesar de sus diferencias.

La ubicación de este palacio dentro del espacio público y sus características formales son claros indicadores de sus funciones político-administrativas y escénicoceremoniales. Según Delvendahl (2010: 263-264) este tipo de actividades podrían agruparse en un complejo «político-escénico», definiendo al edificio como el lugar donde se ejerce y se exhibe el poder del estrato gubernamental; de esta manera, el Edificio B4 puede ser entendido como la sede del poder local.

Dentro de este particular contexto el programa escultórico pudo actuar como una reiteración de las funciones del edificio, a la vez que mostrar a los grupos reunidos en los espacios públicos los agentes que ejercieron la autoridad política.

En términos funcionales, se puede aseverar que cada fachada del Edificio B4 corresponde a un escenario de exhibición del poder, cada uno participando en un espacio público particular. Bajo esta perspectiva, y tomando más en cuenta el entorno espacial que las imágenes, una posible explicación acerca de las dos caras de la crestería es que ambos frentes repiten a los mismos tres personajes -con ciertas variaciones icónicas- mostrados en escenas parecidas.

Desde un enfoque comparativo, algunos monumentos públicos con imágenes pareadas en recto-verso (arreglo compositivo cercano al de la crestería del B4), presentan dos imágenes distintas de un mismo gobernante (p.ej., Estela C de Copán

demás elementos iconográficos con los que estaban vinculados.

${ }^{17}$ Los grupos reunidos en la Plaza de las Estelas y en la plaza al pie de la colina del A1 pudieron tener una movilidad similar. Velázquez Morlet y Balanzario (comunicación personal, 2015) creen que durante la tercera etapa constructiva existían corredores amplios a ambos lados del B4, permitiendo el flujo de una plaza a otra. Estos corredores fueron reducidos posteriormente al construirse los anexos del palacio en el siglo VII. 
[CPN 4], con dos representaciones de Waxaklajun Ubaah K'awiil [en Baudez 1994, Fig. 7-8]); imágenes que participan en espacios diferentes y que interactúan con elementos constructivos y monumentos específicos. En otras palabras, estas estelas repiten el mismo tipo expresivo (escena y formato escultórico) y el mismo referente (personaje), mientras que las diferencias icónicas señalan que cada imagen contiene un aspecto diferenciado del individuo.

Así, sugiero que en la crestería del B4 el propósito de mostrar a los mismos tres personajes en cada frente responde a la necesidad de integrarlos en espacios discursivos diferentes, interactuando con elementos constructivos y entornos distintos en cada caso (el Templo de los Mascarones hacia el oriente y la Plaza de las Estelas hacia el poniente); tal vez cada frente formaba parte de una etapa distinta de un solo discurso, cuyo mensaje en todo caso estuvo centrado en la expresión del poder político y en quienes lo ejercen ${ }^{18}$.

\section{Discusión. Los edificios A1 y B4: imágenes y mensajes complementarios}

Llegado este punto es necesario recordar que el propósito de este trabajo es encontrar y comprender las conexiones existentes entre los programas escultóricos y los edificios que se acaban de analizar, e indagar sobre el significado y la función del entorno construido del grupo central de Kohunlich.

Para lograr dicho objetivo, partiré del hecho que la tercera etapa constructiva del B4 fue realizada entre 450 y 600 d.C., lapso en el que la crestería de este edificio y los mascarones del A1 fueron visibles. Al respecto, concuerdo con los planteamientos de Criado (1993: 41-44) acerca de la visibilidad de las expresiones culturales, e interpreto la monumentalidad de los programas escultóricos y su ubicación de cara a los espacios públicos como estrategias de comunicación que producen dominio espacial y permanencia temporal; estrategias que son propias de los discursos ideológicos. En este mismo orden de ideas, cabe subrayar que el Edificio B4 fue erigido frente al A1, compartiendo con éste un mismo eje visual que se extiende hasta la Plaza de las Estelas (ver Figura 6) ${ }^{19}$.

Iniciaré interpretando que ambos programas escultóricos proclaman la majestuosidad y la sacralidad de la figura real y del linaje (Salazar 2015). No obstante, es patente el contraste entre las dos escenas, cada una concentrada en expresar distintas dimensiones y aspectos de los personajes. En efecto, mientras los mascarones del A1 recrean y sitúan en el entorno construido el proceso de renacimiento de un gobernante y su concurrencia con el dios solar, la crestería del B4 se centra en la expresión del poder político y en quienes lo ejercen.

Contrastes similares se observan en otros monumentos del Preclásico y del Clásico Temprano, por ejemplo, en las Estelas 2 de Tak'alik' Ab'aj y 31 de Tikal y en el Monumento 160 de Toniná (Figuras 10a, b, c). Todos muestran insistentemente a re-

\footnotetext{
${ }^{18}$ Nalda (2004: 85) propone que la crestería muestra un grupo de personas de estatus similar, y la interpreta como evidencia de un gobierno compartido en Kohunlich. Debido al deterioro de las imágenes y a la falta de textos asociados su interpretación carece de sustentos claros. La crestería, incluso, podría mostrar personajes de un mismo linaje real, pero que no necesariamente ejercieron el poder al mismo tiempo (p.ej., Altar Q de Copán).

${ }^{19}$ De acuerdo con Nalda, Balanzario y Maciel (1999), la relación espacial A1 - B4 pudo establecerse desde la primera etapa constructiva del B4, $c a$. 200-400 d.C., cuando dicho edificio pudo ser solamente una plataforma con dos escalinatas de acceso (caras oriente y poniente) coronada por una estructura de material perecedero.
} 


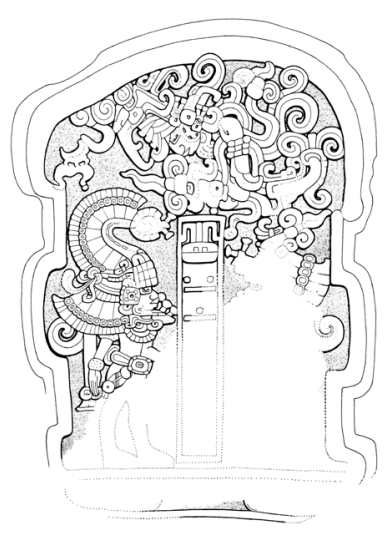

a

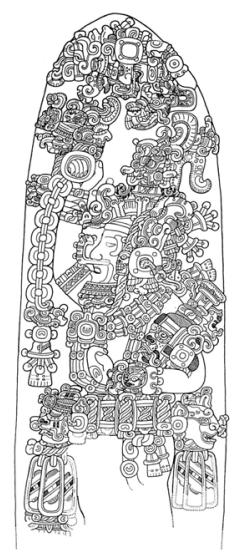

b

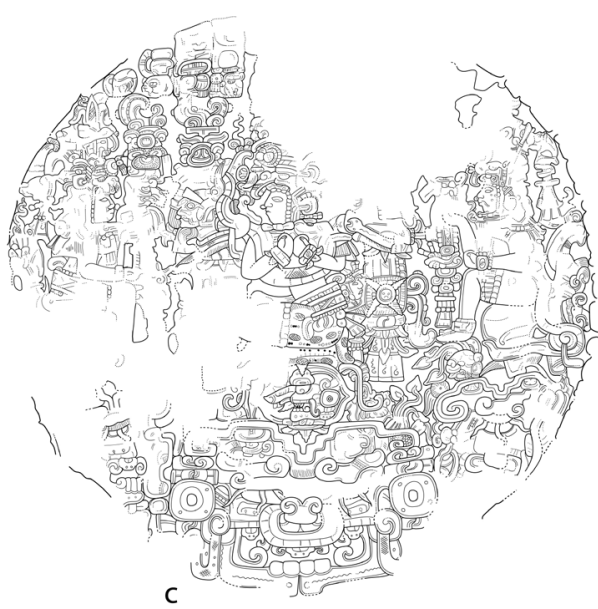

Figura 10. a) Estela 2 de Takalik Abaj; b) Estela 31 de Tikal; c) detalle del Monumento 160 de Toniná (dibujos: a, James Porter; b, John Montgomery; c, Daniel Salazar).

yes activos en el oficio del poder mientras se encuentran en presencia de uno o varios antepasados, quienes ocupan el cielo y están parcialmente fusionados con K'inich, o renacen de montañas floridas ostentando insignias reales. Estas escenas expresan la legitimación del poder a través del vínculo con los antepasados, quienes en todo caso sancionan el derecho del rey a gobernar (McAnany 1995: 125, 1998: 281-287). En consecuencia, la sacralización de los antepasados reales, su enlace o fusión con los dioses y su calidad de seres sobrehumanos con atributos divinos son poderosas estrategias políticas que consolidan y comunican el origen y la esencia sagrada del linaje y del oficio real (Helms 1998: 10). Al respecto, Houston y Stuart (1996: 296) nos dicen que este tratamiento y estatus fue común en los fundadores de linaje o en los antepasados de renombre durante el período Clásico, quienes además fueron integrados en la «mitología del estado» por sus sucesores (Martin 2016: 533) ${ }^{20}$.

Estas mismas ideas pueden manifestarse a través del entorno construido, donde los templos funerarios y su imaginería reproducen un esquema cosmológico, a la vez que comunican la memoria de los gobernantes muertos y generan narrativas con ellos como protagonistas. Al colocar monumentos frente a los templos funerarios o en estrecho vínculo espacial, se enlaza con dichos personajes, se les rinde culto y se produce un diálogo entre generaciones de reyes, promoviendo con ello discursos de continuidad dinástica (O’Neil 2012: 106-112; Rich y Matute 2014: 68, 75; Scherer 2015: 181;). Al respecto, concuerdo con García Capistrán (2014: 69) cuando menciona que, tras su muerte, los gobernantes adquieren el estatus de antepasados que con el transcurrir del tiempo pudieron ser concebidos como héroes culturales y patrones de un linaje, o incluso, de toda una comunidad. Esto explicaría la ubicación de los templos funerarios en el espacio público y su integración en discursos de poder dirigidos a un amplio rango de población. Casos paradigmáticos de esta práctica y uso del espacio son el Templo 10L-16 de Copán, sus sucesivas fases constructivas

\footnotetext{
${ }^{20}$ Desafortunadamente, en el caso de Kohunlich no existe la suficiente información para asegurar que el gobernante sepultado en el Edificio A1 fue un fundador dinástico; cabe destacar, sin embargo, que el recinto funerario y las imágenes que lo representan sí cumplen con un patrón recurrente en los fundadores de linajes.
} 
y monumentos asociados (Taube 2004), los edificios F8-1 y M7-1 de El Zotz y la relación espacial entre ellos (Garrison 2012) y la Estructura O-13 de Piedras Negras, con más de catorce monumentos dedicados y colocados frente al edificio o sobre sus terrazas (O’Neil 2012: 140).

Entornos construidos con estas características pueden ser entendidos como medios de expresión cultural producidos y organizados por los grupos de élite y las instituciones, pero en cuyo significado y función participa la comunidad. En espacios como estos se construye y preserva una memoria cultural (Kupprat 2015), se forja una identidad colectiva y se reproducen y fortalecen las estructuras sociales y las relaciones simbólicas del poder. Para DeMarrais y sus colaboradores (1996: 1617), el entorno construido es una forma de materializar una ideología; es decir, la transformación de un sistema de ideas y creencias en un medio físico y perceptible.

Con todo lo expuesto anteriormente, vemos que en el entorno construido de Kohunlich se recrean dos espacios y recintos perfectamente diferenciados, cuyos conceptos son mediados por las imágenes, las funciones y las características de los edificios: el A1 y la colina, como lugar de veneración ancestral, más elevado y cercano al ámbito celestial y de los dioses; mientras que la sede del poder local (el Edificio B4) y su plaza asociada (Plaza de las Estelas) operan en una dimensión más terrenal y secular. De esta manera se divide semánticamente el entorno, respondiendo a necesidades de representación y de significación de las distintas figuras reales. Algo parecido se observa en los monumentos referidos en las Figuras 10a-c, y en el entorno construido de El Zotz, entre los edificios F8-1 y M7-1.

Considerando todas las ideas hasta aquí expuestas, propongo que en Kohunlich tanto el entorno construido alrededor de los edificios A1 y B4 como el mensaje y la interacción de ambos edificios y sus programas escultóricos, tuvieron la intención de vincular el oficio del poder y el linaje real con un antepasado prestigioso y sagrado, al menos durante el lapso 450-600 d.C.

Debido a la particular morfología del B4, con dos fachadas y dos caras en su crestería, sugiero que el discurso político pudo tener dos etapas, una enfocada en la expresión del poder y la exaltación de las figuras reales frente al gran público reunido en la Plaza de las Estelas; y otra etapa en la que el oficio real se complementó y consolidó a través del vínculo entre los gobernantes y el antepasado -probablemente emitiendo un mensaje de arraigo ancestral y autoctonía de la autoridad (Michelet y Arnauld 2006)-, contando para ello con el público reunido en la plaza al pie de la colina del A1. En tal caso, la construcción del B4 y su crestería (posterior al A1) puede entenderse como un esfuerzo por conectar el orden político y el linaje regente con su predecesor.

En síntesis, planteo que el entorno construido de Kohunlich es un medio de almacenamiento y reproducción de una memoria cultural y de conocimientos compartidos por la sociedad. Se trata de un espacio discursivo -y es aquí donde radica su significado integral- configurado bajo principios cosmológicos y que tuvo como finalidad primaria concretar y expresar los fundamentos ideológicos del poder.

\section{Conclusión}

Este estudio, que partió de una idea general acerca de las posibles conexiones entre el Templo de los Mascarones y el Palacio de las Estelas de Kohunlich (Nalda et al. 
1999; Nalda y Balanzario 2005: 44), ha podido comprobar la existencia de un alto grado de complementación en cuanto al tema y el trasfondo de los programas escultóricos integrados en el espacio; es decir, que entre ellos se logra establecer una integridad efectiva dentro del plano de los contenidos y de significación. Esta complementación también se observa en las funciones y en los significados de los edificios que los contienen. De esta manera se puede sugerir que los elementos componentes del entorno construido de Kohunlich se entrelazan, como una red, para generar un significado integral.

En el caso de Kohunlich, la ideología materializada organiza y da significado al espacio a través de la arquitectura monumental, de sus características formales y de las imágenes que integra. Es en este sentido que este entorno construido puede ser entendido como un paisaje ideológico que adquiere, almacena y reproduce saberes culturales, codificados en un complejo sistema de comunicación accesible a distintos grupos y miembros de la sociedad, pero que es manipulado y controlado por unos cuantos con fines específicos.

Agradecimientos: Mis agradecimientos son para Ana García Barrios, Dominique Michelet, Rogelio Valencia, Felix Kupprat, Hugo García Capistrán, Francisca Zalaquett y Juan Carrillo González, por sus comentarios y sugerencias sobre este texto y las ideas en él expuestas. También agradezco a Adriana Velázquez Morlet, Sandra Balanzario, Luz Evelia Campaña y Alan Maciel por su valioso apoyo y por la información sobre los espacios y los edificios de Kohunlich; así como al Centro INAH Quintana Roo, por otorgarme el permiso y la accesibilidad para dibujar los mascarones del Edificio A1.

\section{Referencias}

Acuña, Mary Jane. 2015. «Royal Death, Tombs, and Cosmic Landscapes: Early Classic Maya Tomb Murals from Río Azul, Guatemala», en Maya Archaeology 3, Charles Golden, Stephen Houston y Joel Skidmore, eds., pp. 168-185. San Francisco: Precolumbia Mesoweb Press.

Ashmore, Wendy y Pamela L. Geller. 2005. «Social Dimensions of Mortuary Space», en Interacting with the Dead. Perspectives on Mortuary Archaeology for the New Millennium, Gordon Ratika, Jane Buikstra, Lane Beck y Sloan Williams, eds., pp. 81-92. Gainesville: University Press of Florida.

Balanzario, Sandra y Enrique Nalda. 2009. «Contextos funerarios tempranos en Kohunlich». Arqueología 41 (mayo-agosto): 64-78.

Baudez, Claude-François. 1994. Maya Sculpture of Copán. The Iconography. Norman y Londres: University of Oklahoma Press.

- 1995. «El espacio mítico del rey maya en el período Clásico». TRACE 28: 29-52. 2006. «De l'aurore à la nuit: le parcours du roi-soleil maya». Journal de la Société des Américanistes 92 (1-2): 41-67.

2013. El dolor redentor. El autosacrificio prehispánico. México: Universidad Nacional Autónoma de México.

Carrere González Alberto y José Saborit Viguer. 2000. Retórica de la pintura. Madrid: Editorial Cátedra.

Clark, John E., Julia Guernsey y Barbara Arroyo. 2010. «Stone Monuments and Preclassic Civilization», en The Place of Stone Monuments. Contexts, Use, and Meaning in 
Mesoamerica's Preclassic Transition, Julia Guernsey, John E. Clark y Barbara Arroyo, eds., pp. 1-26. Washington, D.C.: Dumbarton Oaks Research Library and Collection.

Coggins, Clemency. 1988. «Classic Maya Metaphors of Death and Life». RES: Anthropology and Aesthetics 16: 64-84.

Colas, Pierre. 2003. «K'inich and King. Naming Self and Person among Classic Maya Rulers». Ancient Mesoamerica 14 (2): 269-283.

Criado Boado, Felipe. 1993. «Visibilidad e interpretación del registro arqueológico». Trabajos de Prehistoria 50: 39-56.

Delvendahl, Kai. 2010. Las sedes del poder. Evidencia arqueológica e iconográfica de los conjuntos palaciegos mayas del Clásico Tardio. Mérida: Ediciones de la Universidad Autónoma de Yucatán.

DeMarrais, Elizabeth, Luis Jaime Castillo y Timothy Earle. 1996. «Ideology, Materialization and Power Strategies». Current Anthropology 37 (1): 15-31.

Finamore, Daniel y Stephen D. Houston, eds. 2010. Fiery Pool. The Maya and the Mythic Sea. New Haven: Yale University Press.

Foncerrada de Molina, Marta. 1983. «La exaltación del gobernante maya». Anales del Instituto de Investigaciones Estéticas 53: 7-27. https://doi.org/10.22201/ iie.18703062e.1983.53.1213.

García Barrios, Ana. 2019. «Materia y forma de los dioses mayas del período Clásico». Revista Española de Antropología Americana 49: 151-172. https://doi.org/10.5209/reaa.66526.

García Capistrán, Hugo. 2014. «Religión y política en el Clásico maya: dioses patronos como vía de legitimación del poder», en Socio-Political Strategies among the Maya from the Classic Period to Present. An Introduction, Verónica Vázquez, Rogelio Valencia y Eugenia Gutiérrez, eds., pp. 67-82. BAR International Series 2619. Oxford: Archaeopress.

—. 2019. «La montaña sagrada. Aspectos sobre la legitimación del poder en el Clásico maya». Estudios de Cultura Maya 53: 139-172. https://doi.org/10.19130/iifl. ecm.2019.53.923.

Garrison, Thomas. 2012. Paisaje natural, político y urbano de El Zotz. Conferencia presentada en el Museo Popol Vuh, Universidad Francisco Marroquín, Ciudad de Guatemala, 5 de julio de 2012. https://newmedia.ufm.edu/video/paisaje-natural-politico-y-urbano-de-elzotz/.

Gendrop, Paul. 1984. «La crestería maya y su posible simbolismo dinástico». Cuadernos de Arquitectura Mesoamericana 1: 24-39.

Hellmuth, Nicholas. 1987. Monster und Menschen in der Maya-Kunst. Eine ikonographie der alten Religion. Mexiko und Guatemala. Graz: Akademische Druck-u. Verlagsanstalt.

Helmke, Christophe y Jesper Nielsen. 2015. «The Defeat of the Great Bird in Myth and Royal Pageantry: A Mesoamerican Myth in a Comparative Perspective». Comparative Mythology 1 (1): 23-60.

Helms, Mary. 1998. Access to Origins. Affines, Ancestors and Aristocrats. Austin: University of Texas Press.

Houston, Stephen D. y David Stuart. 1996. «Of Gods, Glyphs and Kings: Divinity and Rulership among the Classic Maya». Antiquity 70 (268): 289-312.

Houston, Stephen D. y Karl A. Taube. 2000. «An Archaeology of the Senses: Perception and Cultural Expression Ancient Mesoamerica». Cambridge Archaeological Journal 10 (2): 261-294.

Houston, Stephen D., Sarah Newman, Thomas Garrison y Edwin Román. 2015. «A Tomb and Its Setting», en Temple of the Night Sun: A Royal Tomb at El Diablo, Guatemala, 
Stephen D. Houston, Sarah Newman, Edwin Román y Thomas Garrison, pp. 12-29. San Francisco: Precolumbia Mesoweb Press.

Hull, Kerry. 2006. «Journey from the Ancient Maya Tomb: Ropes, Roads, and the Point of Departure», en Jaws of the Underworld: Life, Death, and Rebirth among the Ancient Maya, Pierre R. Colas, Geneviève Le Fort y Bodil Liljefors Persson, eds., pp. 43-52. Acta Mesoamericana 16. Markt Schwaben: Verlag Anton Saurwein.

Kováč, Milan, Eva Jobbová y Guido Krempel. 2016. «The Legacy of an Early Maya King: Text, Imagery and Ritual Contexts of Late Preclassic Cache from Structure H-XVI Sub, Uaxactun». Mexicon XXXVIII (1): 9-29.

Kupprat, Felix. 2015. «Analyzing the Past of the Past: A Methodological Proposal for the Study of Cultural Memory among the Classic Maya», en On Methods: How we Know what we Know about the Maya, Harri Kettunen y Christophe Helmke, eds., pp. 25-46. Acta Mesoamericana 28. Markt Schwaben: Verlag Anton Saurwein.

Martin, Simon. 2016. «Ideology and the Classic Maya Polity», en The Origins of Maya States, Loa P. Traxler y Robert J. Sharer, eds., pp. 507-544. Filadelfia: University of Pennsylvania Museum of Archaeology and Anthropology.

McAnany, Patricia. 1995. Living with the Ancestors: Kinship and Kingship in Ancient Maya Society. Austin: University of Texas Press.

- 1998. «Ancestors and the Classic Maya Built Environment», en Function and Meaning in Classic Maya Architecture, Stephen D. Houston, ed., pp. 271-298. Washington, D.C.: Dumbarton Oaks Research Library and Collection.

Michelet, Dominique y M.-Charlotte Arnauld. 2006 «Del arraigo mediante el culto a los ancestros a la reivindicación de un origen extranjero», en Nuevas ciudades, nuevas patrias. Fundación y relocalización de ciudades en Mesoamérica y el Mediterráneo antiguo, $\mathrm{M}^{\mathrm{a}}$ Josefa Iglesias, Rogelio Valencia y Andrés Ciudad, eds., pp. 65-92. Madrid: Sociedad Española de Estudios Mayas. https://dialnet.unirioja.es/servlet/articulo?codigo=2194224.

Nalda, Enrique. 2004. Kohunlich. Emplazamiento y desarrollo histórico. México: Instituto Nacional de Antropología e Historia.

Nalda, Enrique y Sandra Balanzario. 2005. «Kohunlich y Dzibanché. Los últimos años de investigación». Arqueología Mexicana 76: 42-47.

Nalda, Enrique y Adriana Velázquez Morlet. 2000. «Kohunlich. Mitos y reflexiones sobre su historia prehispánica», en Guardianes del tiempo, Adriana Velázquez Morlet, comp., pp. 15-35. México: Universidad de Quintana Roo, Instituto Nacional de Antropología e Historia.

Nalda, Enrique, Sandra Balanzario y Alan Maciel. 1999. Proyecto Kohunlich. Informe al Consejo de Arqueología. Temporada 1999. Vol. 1: Exploraciones arqueológicas. Tomo 1. Informe técnico entregado al Instituto Nacional de Antropología e Historia. México.

Nalda, Enrique, Adriana Velázquez Morlet, Sandra Balanzario y Alan Maciel. 1997. Proyecto Arqueológico Sur de Quintana Roo. 1993-1994. Kohunlich. Volumen 1A. Informe técnico entregado al Instituto Nacional de Antropología e Historia. México.

Nielsen, Jesper y Christophe Helmke. 2018. "'Where the Sun Came into Being'. Rites of Pyrolatry, Transition, and Transformation in Early Classic Teotihuacan», en Smoke, Flames, and the Human Body in Mesoamerican Ritual Practice, Andrew Scherer y Vera Tiesler, eds., pp. 77-107. Washington, D.C.: Dumbarton Oaks Research Library and Collection.

O’Neil, Megan. 2012. Engaging ancient Maya Sculpture at Piedras Negras, Guatemala. Norman: Oklahoma University Press. 
Rich, Michelle y Varinia Matute. 2014. «The Power of the Past: Crafting Meaning at a Royal Funerary Pyramid», en Archeology at El Perú-Waka'. Ancient Maya Performance of Ritual, Memory, and Power, Olivia C. Navarro-Farr y Michelle Rich, eds., pp. 66-84. Tucson: University of Arizona Press.

Salazar Lama, Daniel. 2014. Aj K’an Witz. Montañas, antepasados y escenas de resurrección en el friso de Balamkú, Campeche. Tesis de Maestría en Estudios Mesoamericanos. México: Instituto de Investigaciones Filológicas, Facultad de Filosofía y Letras, Universidad Nacional Autónoma de México.

- 2015. «Formas de sacralizar a la figura real entre los mayas». Journal de la Société des Américanistes 101 (1-2): 11-49. https://journals.openedition.org/jsa/14397.

- 2019. Escultura integrada en la arquitectura maya: tradición y retórica en la representación de los gobernantes (400 a.e.c.-600 e.c.). Tesis de Doctorado en Estudios Mesoamericanos, Universidad Nacional Autónoma de México.

—. En prensa. «El Templo de los Mascarones de Kohunlich: una interpretación simbólica», texto por publicarse en las memorias del I Congreso Internacional de Arquitectura e Iconografía Precolombina de Valencia 2016.

Salazar Lama, Daniel y Ana García Barrios. 2019. «La imagen maya: claves para su análisis. Introducción». Revista Española de Antropología Americana 49: 127-129. https://doi. org/10.5209/reaa.66524.

Scherer, Andrew K. 2015. Mortuary Landscapes of the Classic Maya: Rituals of Body and Soul. Austin: University of Texas Press.

Stuart, David. 2004. «La concha decorada de la tumba del Templo del Búho, Dzibanché», en Los cautivos de Dzibanché, Enrique Nalda, ed., pp. 133-140. México: Instituto Nacional de Antropología e Historia.

- 2010. Comentarios sobre las inscripciones del Templo XIX de Palenque. Precolumbia Mesoweb Press. http://www.mesoweb.com/es/publicaciones/Stuart/TXIX.pdf.

- 2012. «The Name of the Paper: The Mythology of Crowning and Royal Nomenclature on Palenque's Palace Tablet», en Maya Archaeology 2, Charles Golden, Stephen Houston y Joel Skidmore, eds., pp. 116-142. San Francisco: Precolumbia Mesoweb Press.

- 2017. «The Gods of Heaven and Earth. Evidence of Ancient Maya Categories of Gods», en Del saber ha hecho su razón de ser: Homenaje a Alfredo López Austin. Vol. 2., pp. 247-267. México: Instituto de Investigaciones Antropológicas, Universidad Nacional Autónoma de México, Instituto Nacional de Antropología e Historia.

Stuart, David y George Stuart. 2008. Palenque. Eternal City of the Maya. Londres: Thames and Hudson.

Taube, Karl A. 1998. «The Jade Hearth: Centrality, Rulership, and the Classic Maya Temple», en Function and Meaning in Classic Maya Architecture, Stephen D. Houston, ed., pp. 427-478. Washington, D.C.: Dumbarton Oaks Research Library and Collection.

- 2004. «Structure 10L-16 and its Early Classic Antecedents: Fire and the evocation of K'inich Yax K'uk' Mo'», en Understanding Early Classic Copan, Ellen Bell, Marcelo Canuto y Robert Sharer, eds., pp. 265-295. Filadelfia: University of Pennsylvania Museum of Archaeology and Anthropology.

Taube, Karl A., William A. Saturno, David Stuart y Heather Hurst. 2010. Los murales de San Bartolo, El Petén, Guatemala, Parte 2: el mural poniente. Ancient America 10. Barnardsville: Center for Ancient American Studies. http://www.mesoweb.com/bearc/ caa/AA10-es.pdf. 
Tokovinine, Alexandre. 2012. «Writing Color: Words and Images of Colors in Classic Maya Inscriptions». RES: Anthropology and Aesthetics 61/62: 283-299.

Velásquez García, Erik. 2006. «Iconografía real de K’ahk’Tiliw Chan Yo’aat: política y fundación del mundo en Quiriguá, Guatemala», en XXV Coloquio Internacional de Historia del Arte «Francisco de la Maza». La Imagen Politica, Cuauhtémoc Medina, ed., pp. 113-146. México: Instituto de Investigaciones Estéticas, Universidad Nacional Autónoma de México.

- 2015. «Las entidades y las fuerzas anímicas en la cosmovisión maya clásica», en Los Mayas. Voces de Piedra, Alejandra Martínez de Velasco y María Elena Vega, eds., pp. 177-195. Ciudad de México: Turner, Ámbar Diseño, S.C., Universidad Nacional Autónoma de México.

Velázquez Morlet, Adriana. 1995. «Cosmogonía y vida cotidiana en Kohunlich». Arqueología Mexicana 14: 32-36.

Zetina, Sandra. 2007. Análisis de la técnica de manufactura de los mascarones de estuco del Edificio A-1 y B-4 de Kohunlich, Quintana Roo. Tesis de Licenciatura en Restauración de Bienes Muebles. Escuela Nacional de Conservación, Restauración y Museografía, Instituto Nacional de Antropología e Historia. México. 